\title{
Is orientalism bad? Between the communication game and the non-game
}

\author{
Arkadiusz Jabłoński \\ Uniwersytet im. Adama Mickiewicza w Poznaniu \\ yaboo@amu.edu.pl | ORCID: 0000-0002-0812-4142
}

\begin{abstract}
Linguistics deals with communication and its pragmatic effects in terms of dynamic changes in human relationships fostered by the information circulated between the interacting parties. Such relationships may be especially complex in the inter-cultural context, when certain information belonging to the source environment may not be clear to the participants functioning in the target environment. Communication may relate to the facts verified with solely technical means, but also to the unverifiable convictions, views and stereotypes. Its specific manifestation in the contemporary circulation of pop-cultural (and not only) relations is the presence of orientalism-related threads. Some premises on whether such threads should be recognized as harmful and distorting the communication perspective by their very definition - and why - are presented in the paper. The methodology of game research, with reference to the psychological games and the roles of the Child, the Adult and the Parent, being alluded on purpose by the triad of the expert, non-expert and careless narratives, makes it possible to differentiate effectively the verifiable reports on facts from the narratives which, by their very definition, are not subject to verification, and which are often misleading or do not go beyond the harmful stereotypes.
\end{abstract}

Keywords: inter-cultural communication, orientalism, Japan, post-truth, careless narratives

Homo Ludens 1(13)/2020 | ISSN 2080-4555 | @ Polskie Towarzystwo Badania Gier 2020 DoI: 10.14746/HL.2020.13.3 | received: 31.12.2019 | revision: 10.05 .2020 | accepted: 2.12 .2020 



\section{Introduction}

Communication may occur in circumstances when not all participants share the same information on the bare facts and on the cultural context, as in the course of inter-cultural communication. The process may be subject to further complication, since information is often not transferred directly, but via the services of translators, interpreters, messengers, inter-cultural researchers or other agents. While they do not play the central role in the communication process themselves, they may supply the original information content with their biased cultural convictions, often basing on stereotypes and prejudices.

Despite the fact that it is easy nowadays to contact the representatives of foreign cultures or verify inter-cultural facts, communication is not automatic. In fact, also due to the frequent lack of immediate contact between the source and target parties of the process, inter-cultural contacts may result with miscommunication, leading to communication failures (Hidasi, 1999, p. 277) and negative stereotypes, which impact both the immediate results of the process and the future contacts of whole ethnic groups (Duszak, 1998, p. 332). The reason for this may be that it is hard to distinguish between facts and convictions in a multicontext environment. As a solution, the description of different kinds of narratives based on conscious though indirect reference to the game research methodology is proposed in order to differentiate between the ludic, playful properties of games and the tangible parameters of the reality. In this paper, three kinds of narratives, expert, non-expert and careless, are described and differentiated, with the use of actual examples of narratives.

\section{Games as tools of communication pragmatics}

The game framework is utilized in the research of pragmatic properties of messages. This methodology is rooted both in the ludic properties of games (Huizinga, 1949; Caillois, 2001) and in their semiotic (Guiraud, 1975), theatrical (Goffman 1956) as well as psychological features (Berne, 1999). It may further be extended in terms of an objective of a procedure 
(Austin, 1962), the reality of everyday life (Berger, Luckmann, 1966) or the phatic properties of games (Jabłoński, 2009). The basic, binary opposition embodied in these relations is between the (conventional or creative) game and the (tangible) reality.

\section{The family triad}

Facts and quasi-facts may not be easy to distinguish on the inter-cultural stage. Also the motivation of the broadcasters of numerous inter-cultural narratives requires thorough clarification. While not every deviation from tangible facts fosters miscommunication, the inherent heterogeneity of the inter-cultural context may create opportunities for the interpretation of facts of the source environment in a creative, playful manner. In this aspect, fiction should be differentiated from the consciously obscure or xenophobic explanations. The selection of description model for the purpose of this paper was made while taking into account also some psychological factors that may govern the application of the interpretation patterns.

It is in terms of psychological games that a family triad is defined by Berne. Its elements, the Child, the Adult and the Parent, are linked to the external information interpretation schemes:

CHILD: „intuition, creativity, spontaneous drive, enjoyment”, ADULT: „necessary for survival [...] processes data and computes the probabilities which are essential for dealing effectively with the outside world",

PARENT: „it makes many responses automatic, which conserves a great deal of time and energy" - the Parent's activity is performed according to a presupposed thesis: “That's the way it's done." (Berne, 1964, pp. 23-28).

As a tentative proposition of the model constructed for the purposes of this paper, the ADULT constituent may be assigned as the non-game component, relying on the verifiable, tangible data to be collected and systematized for the effective description of the heterogeneous intercultural facts. The CHILD and the PARENT constituents are opposed to it, deviating in various ways from tangible facts, with multi-layered impact on the communication efficacy. 


\section{Narratives}

There are roughly three kinds of narratives (including the inter-cultural narratives), in terms of Jabłoński, 2016, each to be assigned to a different element of the family triad.

The EXPERT narratives are no-games. The basic difference is between facts and falsity. They are governed by the ADULT, being typical of such textual genres as scientific description of verifiable facts, with clear definitions of basic concepts. Encyclopedic entries, press news, scientific papers, weather reports or stock exchange data serve as examples.

The NON-EXPERT narratives may be described in terms of games. They are governed by the CHILD. Some elements of the EXPERT narratives may also be utilised, the facts being opposed to the subjective, creative interpretation. The verifiability of this group of narratives is only partial, being based on certain convention, with relatively clear rules. Hyperboles and overstatements may occur. Typical examples are fiction, poetry, essays and language games (Jabłoński, 2016, with changes).

The CARELESS narratives are based on anti-information. They are governed by the PARENT acting according to a certain presupposed thesis. Their main focus is surprisingly often to pose as the EXPERT narrative. They may contain stereotypes, prejudices and statements based solely on individual views, loosely related to the verifiable facts. They may utilize the elements of the EXPERT and the NON-EXPERT narratives, but only to the extent that these support the thesis in focus. The thesis is preferred over the fictional convention of narration, the result, in terms of inter-cultural communication, being often the "dehumanized thought... disregarding, essentializing, denuding the humanity of another culture, people or geographical region" (Said, 2003, p. 108).

The NON-EXPERT narratives, despite the contemporary development of information-processing techniques that could make it extremely easy to verify their false content, paradoxically seem to occupy a significant part of the information circulation band. Moreover, despite the obvious fact that stereotypes are obsolete and false, they proliferate quickly and are hard to eradicate from the public space. Their subject is often Japan, its people and culture. Some of the author's previous publications, mainly in Polish, describe numerous aspects of careless narratives as well 
as their xenophobic features and the harmful impact on the processes of cross-cultural communication, including the processes of translation and interpretation (cf. Jabłoński, 2009, 2013, 2015, 2016).

\section{EXPERT narrative: Japanese patterns of behaviour}

The EXPERT narratives use clear-cut concepts and verifiable description schemes. As an example, one may quote an almost half a century old, but by no means obsolete, classification of communication patterns provided by Takie Sugiyama-Lebra (1976, p. 112). The author proposes two basic patterns of Japanese behaviour: INTIMATE and RITUAL. The classification is simplified on purpose, being based on clearly defined notions.

\begin{tabular}{|ccc}
\hline & omote 'front (official)' & ura 'back (hidden)' \\
\hline uchi 'in (internal)' & - (NONE) & INTIMATE \\
\hline soto 'out (external)' & RITUAL & ANOMIC
\end{tabular}

Interaction without a pattern is judged impossible. When the INTIMATE pattern is unavailable, the RITUAL one is applied. In the described pattern the possibility to combine the in and the front parameters is excluded, with the ANOMIC pattern used exclusively for dealing with unpredictable situations, not covered by the RITUAL one.

The proposition is not devised to serve as the description of all possible interactions. It is useful to explain the flow of selected schematic phenomena. It may also be further discussed and amended. As such, it fulfils the requirements of the EXPERT narrative.

\section{EXPERT narrative with NON-EXPERT elements: Japanese and strangers}

The EXPERT narratives may utilise the elements of the NON-EXPERT narratives, for rhetorical effects. It is for this reason that one may encounter the following passages in the widely known description of the Japanese society by Nakane. 
In everyday affairs a man who has no awareness of relative rank is not able to speak or even sit and eat (Nakane, 1970, p. 30).

The Japanese have failed to develop any social manner properly applicable to strangers, to people from 'outside'. In the store of Japanese etiquette there are only two basic patterns available: one which applies to a 'superior' and another which applies to an 'inferior' ... This produces discomfort during contact with a stranger... foreigner or Japanese (Nakane, 1970, p. 130).

The EXPERT narrative does not seem to support the lay view that "the Japanese are closed to the outside". Some simplifications may help to explain the concepts defined in advance.

\section{EXPERT narratives and overstatements: situations and labels}

The EXPERT narratives are not free from overstatements. In her interesting paper on the inadequacy of folk labels in the cross-cultural analysis of speech genres, Wierzbicka maintains that "Japanese doesn't have a verb corresponding to the English verb to thank":

thank
(a) I know: you did something good for me
(b) I feel something good towards you because of this
(c) I say this because I want you to feel something good

kansha suru

(a) I know: you did something good for me

(b) I feel something good towards you because of this

(b') I know: I couldn't do something good like this for you

(b") I feel something bad because of this

(c) I say this because I think I should say it (Wierzbicka, 2003, p. 157)

There are doubts whether the quoted elements may be compared in this way. Issues may be pointed out also in the proposed definition metalanguage as well as in the choice of informants (Jabłoński, 2013, pp. 212-213). The comparison could be supplemented with the description of the thanking procedure in terms of the RITUAL pattern (Sugiyama-Lebra, 1976) of 'superior' and 'inferior' schemes (Nakane, 1970). The narrative, 
however, is based on clear premises and reveals features necessary to consider it as an EXPERT narrative.

\section{NON-EXPERT narrative: form and content}

The NON-EXPERT fragments of the EXPERT narratives may contain the information not supported by sufficient evidence or they may be deprived of term definitions. The following statement may be read in an otherwise very instructive account on Japanese honorifics:

Japanese has an elaborate set of polite formulas, stock phrases designed to smooth every conceivable social situation. A foreigner who memorizes about twenty or thirty of the common situational exchanges can circulate in Japanese society with surprising success, even if he knows no other expressions; he soon gets the feeling that Japanese conversation is all formula, with no content (Martin, 1964)

While the author probably did not mean it, the quoted fragment may be interpreted as a proof that it is only in the Japanese society that the message content differs from its form. The statement, not based on any definition of a 'stock phrase', may be a specific sign of a time when it was formed. In the contemporary EXPERT relations this is usually avoided.

\section{NON-EXPERT narrative $\neq$ CARELESS narrative with ludic content}

The NON-EXPERT narrative does not equal the CARELESS one. The below quotes, provided with their English translations, come from Polish pop songs and from a drama.

Są Japonki bardzo grzeczne, ciche, ciemnookie,

Wschodnie gejsze niedzisiejsze, skośne, niewysokie,

Może dałbym się Japonce nawet

zauroczyć,

Ale jak tu takiej Chince spojrzeć prosto w oczy? (Rosiewicz, 1980).
'There are Japanese girls, very polite, timid and dark-eyed, The old-fashioned Eastern geishas, slant-eyed and short.

Well, I could perhaps be enthralled by a Japanese, But how do you look straight in the eye of a Chinese girl?' 
Topiłem smutki w butelce wódki, Obok Japończyk do lustra pił. Pytam źóttego: „Powiedz, dlaczego Wciąż jesteś smutny?" On na to mi [...] (Olewicz, 1994).

Czemu nie karmiłam go wódką od dziecka? Byłby przynajmniej jak te pieski japońskie, co od szczeniaka wódkę żłopia - nie byłby tym wstrętnym dorosłym niczym (Witkiewicz, 1985, p. 374).
'Sinking my sorrows in a bottle of vodka

I saw a Japanese guy beside me: drinking alone I asked the yellow guy: 'Tell me why are you still sad?' and that's what he said: ...'

'Why have I not fed him with vodka since he was a child? He could be at least like those Japanese doggies which swill vodka as puppies - not this disgusting adult nobody.'

The italics above mark the overtly xenophobic or false information, like the CARELESS lack of differentiation between a Japanese and a Chinese. The humorous context (regardless of whether the passages are actually going to be considered funny in the contemporary context) is apparently expected to justify such a NON-EXPERT usage.

\section{CARELESS narrative: 'the country of wilted cherry blossom'}

The CARELESS narratives surprisingly often rely on irresponsible conclusions drawn from verifiable facts concerning Japan. What could be an interesting article on the contemporary issues and challenges of Japan and its society may easily turn into a series of selected EXPERT facts with NONEXPERT ready diagnoses and therapy recommendations, as in the fragment below. As may be seen, overtly presupposed conclusions are not avoided:

Confucian obedience towards seniors paralyzes the enterprise. Although in the latest Global Innovation Index Japan advanced from the $21^{\text {st }}$ to the $19^{\text {th }}$ position, its researchers are often awarded Ig Nobels, the irreverent prizes for the most useless and absurd inventions. The Japanese startup has chances for success equal to a Japanese woman working as a manager (Tomański, 2015).

The author does not bother to define the basic concepts, mixing the facts with stereotypes and explicitly false information (such as the insinuated purpose of the Ig Nobel prize). In the manner typical for the CARELESS 
narratives, it is solely the author of the article that acts as an expert and is able to interpret the facts. The answer is simple: Japan needs more immigrants (Tomański, 2015). The reliability of the fragment, however, is low, despite the fact that the author seems to have obtained the competences sufficient to provide more balanced opinions.

\section{CARRELESS narrative: 'a defeated dog'}

Numerous CARELESS narratives in Poland rely on the stereotype of the Japanese women as humiliated and discriminated. The texts by Joanna Bator (2004, 2014), a pioneer of this trend on the Polish book market, may serve as rich sources of stereotypes, fabrications and irresponsible insinuations on Japan and the Japanese, produced, as the author states, by a person "working at one of the universities in Tokyo" (Bator, 2004, back cover; this information, repeated throughout the book, is rather false: Bator was granted an internship in Japan and probably even the status of her visa actually prohibited her employment). Due to their low reliability, they may be classified as CARELESs narratives, governed by the presupposed PARENT's attitude to facts, but compiled in a NON-EXPERT manner of a playful CHILD - creative, jolly and flippant.

A new representative of the trend is Karolina Bednarz, whose narrative, while not less CARELESS than that by Bator, is written from the rigid PARENT'S perspective, in an extremely serious manner, as a pretended set of reportages, being in fact a collection of biased essays based on selectively chosen facts from the Japanese culture and reality (Bednarz, 2018). The author, contrary to Bator, is apparently fluent in Japanese and capable to examine the facts of Japan in a reliable manner. What prevents her from that is the presupposed thesis of the PARENT that all women of Japan are subjects to systemic discrimination. Similarly to Bator, the fact that Japanese women do not face discrimination in many aspects in which women in Poland, the home country of Bator and Bednarz, do, is omitted. It is not clear why the sex discrimination is described in Japan, and not in any other country.

An example of the above-mentioned PARENT's reasoning may be found in a chapter entitled Defeated dog (Bednarz, 2018, pp. 77-83), published 
earlier as an article in a magazine. The title does not allude to an existing and well-known Japanese idiom related to the characteristic behaviour of howling defeated dogs. It is intended to imply that the Japanese "women who do not comply with the expectations of the society" (allegedly: all of them) "are called defeated dogs", which is not necessarily true. While this (deliberate or not) overstatement could probably be solved by consulting a Japanese dictionary, it is interesting to note that the main character of the chapter, Ms. Akiko, lives with a partner married to another woman. His wife knows about the affair, but refuses to divorce him, looking after his elderly parents, which further supports Akiko's carefree life. Who is discriminated then? Akiko's friend dares to call her "a defeated dog", since she rejects her social obligations, caring only for her own comfort and acting solely at her own will. Surprisingly, in the opinion of Bednarz it is Akiko, not her lover's wife, who suffers, misunderstood by the cruel Japanese society. Such CARELEss, distorted interpretation of facts may be found also in another dozen of chapters of the collection (Bednarz, 2018). The PARENT's thesis is clearly more important than verifiable facts.

\section{CARELESS narrative: 'teeth-clenching', 'a toolbox set for dealing with accidents'}

Another representative example of a CARELESS narrative by Bednarz is her article on the Japanese educational system. Quite apart from how educational systems are ranked in other countries of the world, it is hard to guess what a reader may benefit from a text which in its very title uses an expression "the school of teeth-clenching", and has the only clear conclusion saying "the most important lesson is not to stick out of the crowd" (Bednarz, 2019). Certain cases of pathology mentioned in the text are described selectively, leading to a clear but false conclusion that bullying is found only in Japanese schools.

A very similar picture of Japan emerges in another, earlier article by the same author. Japan is described as a terrible country with the number of suicides so high that there are special "toolbox sets for dealing with the accidents resulting with injury or death" at the disposal of each 
railway station's personnel. Interestingly enough, Bednarz herself does not propose any alternative solution for dealing with the cases of suicide by the railway companies. The text seems to provide a careful selection of ultimate proofs of Japanese inhumanity and peculiarity (Bednarz, 2016). Several things remain constant: it is unclear why it is Japan that the author intends to describe and why the right to diagnose the Japanese culture as a whole is usurped by her. The only conceivable reason why the article on the alleged faults specific to the Japanese educational system (Bednarz, 2019) appears in the magazine is the advertisement of "an Asian event" printed under it. It is probably also the case of other CARELESS narratives, which, due to their inherently gaudy character, quite independently of their author's actual intentions and motivations, are rather utilised as advertising tools than with the purpose to explain anything regarding a heterogeneous culture. This, unfortunately, does not diminish their negative impact on the public debate. They remain valid as language messages and their content may be interpreted literally, with all possible consequences.

\section{Ontological issues}

The CARELESS narratives quoted above reveal a characteristic shift from the facts to their instant, usurped interpretations. They are created and circulated according to the convention of a peculiar communication game, performed from the perspective of a CHILD (with a loose connection between facts and reality) or a PARENT (based on mentioning only the facts in accordance with a presupposed thesis). The Japanese setting, considered inexplicable and exotic, enables the authors to skip the definitions of basic concepts, to use widespread stereotypes, hyperboles or even fabrications (also with regard to the facts that could easily be explained). The authors blatantly usurp the right to act as experts on the Japanese culture as a whole with the clear objective to judge the facts and diagnose the alleged faults of the heterogeneous culture in a purely xenophobic manner. This does not change the rather faint informational output of the texts in question. The quality of analyses provided by the CARELEss narratives is indeed surprisingly low. The anti-information presented in 
them belongs to the world of post-truth. Their receivers usually have no chance to access the facts. One may wonder whether and why the facts and their relations seem to be rather unappealing to the authors of the narratives, who prefer selective description and superficial conclusions. While there is no overt obligation for the reportage to mention the truth, the whole truth and only the truth, the manner of narration performed solely at the authors' whim is a clear violation of descriptive reliability.

\section{Conclusions}

Orientalism-related CARELESS narratives constitute a sub-type of communication games elaborately disguised as EXPERT reports. In the context of inter-cultural communication they are harmful in their tendency to popularise, at best, not-too-sophisticated stereotypes (Jabłoński, 2013, pp. 197-210), or, worse, even fabrications. The claim that the common sense of the receiver should make it possible to distinguish between the EXPERT, NON-EXPERT and CARELESS narratives may not be justified. The facts of heterogeneous cultures are distorted in the process of their tendentious interpretation to provide a false, dehumanised picture of people, objects and phenomena the receivers may never meet or experience themselves. Being served with a mix of facts and fabrications, they may have no chance to develop a critical attitude to it. The intentionally false theses propagated quickly in this manner seem to be beyond critique. The new media deliver false relations with amazing frequency and quantity, which is much more than an individual is able to process. Their qualitative shortcomings seem to be quickly overridden by the quantitative abundance. Even recounting basic facts takes more time and effort than does reading a piece or even a series of CARELESS narratives. Most receivers do not seem to be interested in long explanations of complicated facts. Simple statements, quick analyses, quasi-truths and post-truths sell better. In this way, the stereotypes on the heterogeneous people, phenomena and cultures are disseminated to the extent unknown in the pre-mass-information era.

The technique of anti-communication and anti-information is based on a pragmatic fraud made for sale. It is a subject of a package deal, an 
act of selling a pig in a poke, with the other (hidden) element advertised or sometimes simply the very fee for the careless narrative being the actual objective of transaction. Both in Internet services and in paper media the CARELESS narratives are published along with the EXPERT and the NON-EXPERT narratives, with no way for a non-expert to differentiate between them. It seems that there is no solution to this. It may even be supposed that there is no limit of absurdity in the CARELESs narratives or that the existing limits are continuously subject to expansion. Of which the title of another recent magazine article seems to be a vivid proof: "An absurd ban. Women may not wear glasses. They lack the feminine look" (mk, 2019).

With no instant way to eradicate the CARELESS narratives from the information circle, the awareness of their existence and the outline of tricks utilised by them provided above may help to unmask them. The post-truth may only be falsified by truth. There is no way around.

\section{References}

Austin, J. L. (1962). How to Do Things With Words. Cambridge, Massachusetts: Harvard University Press.

Bator, J. (2004). Japoński wachlarz [A Japanese fan]. Warszawa: Twój Styl. Bator, J. (2014). Rekin z parku Yoyogi [A shark of the Yoyogi Park]. Warszawa: Grupa Wydawnicza Foksal.

Bednarz, K. (2016). Samobójstwa w Japonii. Zestaw do wypadków z udziałem ludzi [Suicides in Japan: A set for dealing with accidents resulting in injury or death]. Gazeta Wyborcza. Online: <https://wyborcza.pl/ duzyformat/1,127290,20558366, samobojstwa-w-japonii-zestaw-dowypadkow-z-udzialem-ludzi.html>. Accessed: 15 November 2019.

Bednarz, K. (2018). Kwiaty w pudetku [Flowers in the box]. Warszawa: Czarne.

Bednarz, K. (2019). Japońska szkoła zaciskania zębów [The Japanese school of teeth-clenching]. Pismo. Online: <https://magazynpismo. pl/japonska-szkola-edukacja-przemoc>. Accessed: 15 November 2019. Berger, P. L., Luckmann T. (1966). The Social Construction of Reality: A Treatise in the Sociology of Knowledge. London, New York: Penguin. 
Berne, E. (1964). Games People Play: The Psychology of Human Relationships. New York: Grove Press.

Caillois, R. (2001). Man, Play and Games (transl. M. Barash). Urbana and Chicago: University of Illinois Press.

Duszak, A. (1998). Tekst, dyskurs, komunikacja międzykulturowa [Text, discourse, inter-cultural communication]. Warszawa: Wydawnictwo Naukowe PWN.

Goffman, E. (1956). The Presentation of Self in Everyday Life. Edinburgh: University of Edinburgh.

Guiraud, P. (1975). Semiology (transl. G. Gross). London, Boston and Henley: Routledge \& Kegan Paul.

Hidasi, J. (1999). Cases of Miscommunication between Europeans and Japanese. In R. Huszcza, A. Kozyra (eds.), Proceedings of Warsaw Symposium on Japanese Studies, 23-26 November 1994 (pp. 275-284). Warszawa: Dialog.

Huizinga, J. (1949). Homo Ludens: A Study of the Play-Element in Culture. London, Boston and Henley: Routledge \& Kegan Paul.

Jabłoński, A. (2009). Gry, procedury, przewidywalność - w kontekście polsko-japońskiej komunikacji międzykulturowej [Games, procedures, predictability - in the context of Polish-Japanese intercultural communication]. Homo Ludens, 1(1), 103-112.

Jabłoński, A. (2013). Homeostaza tekstu. Tłumaczenie i komunikacja międzykulturowa $w$ perspektywie polsko-japońskiej [Homeostasis of text: Translation, interpretation and intercultural communication in the Polish-Japanese perspective]. Poznań: Wydawnictwo Naukowe UAM. Jabłoński, A. (2015). Japoński miszmasz [A Japanese mishmash]. Baranowo: Jeżeli P to Q.

Jabłoński, A. (2016). Japońskie alter ego. Jeszcze o antyinformacji w „narracjach niedbałych" [A Japanese alter ego: More on the anti-information in the 'careless narratives']. Homo Ludens, 9(1), 2016, 53-63.

Martin, S. E. (1964). Speech Levels in Japan and Korea. In D. Hymes (red.), Language in Culture and Society (pp. 407-415). New York, Evanston, London: Harper \& Row, Publishers.

mk (2019). Absurdalny zakaz w Japonii. Kobiety nie mogą nosić okularów. Bo tracą kobiecość [An absurd ban. Women may not wear glasses. They lack the feminine look]" Wysokie obcasy. <https://www. 
wysokieobcasy.pl/wysokie-obcasy/7,163229,25392156, absurdalny-zakaz-w-japonii-kobiety-nie-moga-nosic-okularow.html>. Accessed: 15 November 2019.

Nakane, C. (1970). Japanese Society. Berkeley and Los Angeles: University of California Press.

Said, E. W. (2003). Orientalism. London: Penguin.

Sugiyama-Lebra T. (1976). Japanese Patterns of Behavior. Honolulu: University of Hawaii Press.

Olewicz, B. (1994). Na co komu dziś [I don't need today]. Lyrics online: $<$ https://www.tekstowo.pl/piosenka,lady_pank,na_co_komu_dzis. html>. Accessed: 15 November 2019.

Rosiewicz, A. (1980). Najwięcej witaminy [Most vital]. Lyrics online: <https://www.tekstowo.pl/piosenka,andrzej_rosiewicz,najwiecej_ witaminy.html>. Accessed: 15 November 2019.

Tomański, R. (2015). Japonia. Kraj przywiędłej wiśni [Japan: The country of wilted cherry blossom]. Online: <http://wyborcza.pl/magazy n/1,149044,19074844,japonia-kraj-przywiedlej-wisni.html>. Accessed: 15 November 2019.

Wierzbicka, A. (2003). Cross-Cultural Pragmatics: The Semantics of Human Interaction. Berlin: Mouton de Gruyter.

Witkiewicz, S. I. (1985). Matka [Mother]. In Dzieła wybrane. T. V. Dramaty** [selected works. Vol. 5. Dramas, part 2]. Warszawa: Państwowy Instytut Wydawniczy.

dr hab. Arkadiusz Jabłoński - prof. UAM, Zakład Japonistyki, Instytut Orientalistyki, Wydział Neofilologii Uniwersytetu im. Adama Mickiewicza w Poznaniu

\section{Czy orientalizm jest zły? Między komunikacyjną grą a niegrą}

Abstrakt: Językoznawstwo zajmuje się komunikacją i jej pragmatycznymi efektami w kategoriach dynamicznych zmian w stanie stosunków międzyludzkich powodowanych przez informację przekazywaną między stronami interakcji. Stosunki takie mogą być szczególnie złożone w kontekście międzykulturowym, gdy pewne informacje przynależne do kontekstu źródłowego mogą nie być zrozumiałe dla uczestników funkcjonujących 
w kontekście docelowym. Komunikacja może dotyczyć weryfikowalnych wyłącznie technicznie faktów, lecz także nieweryfikowalnych przekonań, poglądów i stereotypów. Jej specyficzny przejaw we współczesnym obiegu popkulturowym (i nie tylko) to obecność wątków orientalistycznych. Pewne przesłanki służące uzyskaniu odpowiedzi na pytanie, czy i dlaczego wątki takie można uznać za z gruntu złe i wypaczające perspektywę komunikacyjną, przedstawiono w artykule. Metodologia badania gier, z odniesieniem do gier psychologicznych i ról Dziecka, Dorosłego oraz Rodzica, do jakiej celowo nawiązuje triada narracji fachowych, niefachowych i niedbałych, pozwala na efektywne oddzielenie weryfikowalnych doniesień na temat faktów od relacji z definicji niepodlegających weryfikacji, często mylących lub niewykraczających poza szkodliwe stereotypy.

Słowa kluczowe: komunikacja międzykulturowa, orientalizm, Japonia, postprawda, relacje niedbałe 
